\title{
Cancer Prevention as the Key to Long-Term Population Health: An Interview with Dr. Carolyn Gotay
}

\author{
Armaan K. Malhotra, BSc ${ }^{1}$ \\ ${ }^{1}$ Faculty of Medicine, University of British Columbia
}

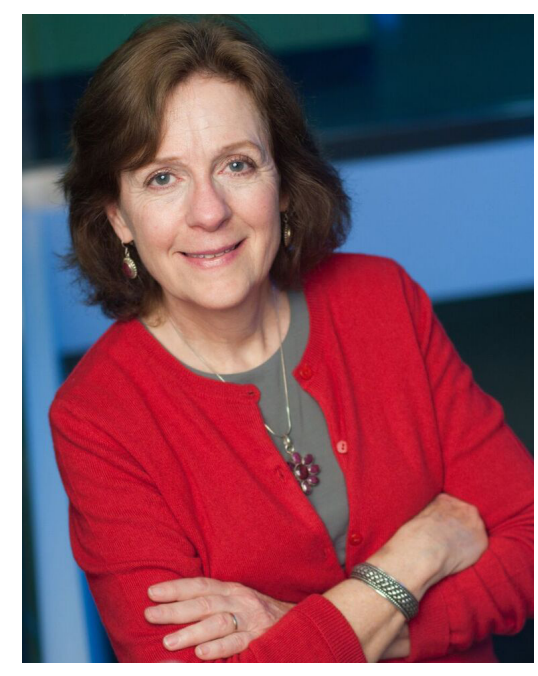

A BSTRACT

Dr. Carolyn Gotay is Professor and Canadian Cancer Society Chair in Cancer Primary Prevention at the University of British Columbia (UBC). Her training began at Duke University and continued with a PhD in Psychology from the University of Maryland. During her first position at the University of Calgary, she became interested in the relationship between psychology and cancer, which would become the focus of her subsequent work. Dr. Gotay has held positions at Gettysburg College, the University of Calgary, and the National Cancer Institute (U.S.) where she acted as a Health Scientist Administrator. Following these positions, she began at the University of Hawaii, where she worked as the Director of the Cancer Prevention and Control Program. Throughout these various roles, her primary prevention interests were multi-faceted; they included a focus on clinical trials investigating quality of life as well as understanding end-of-life care and the psychosocial wellbeing of patients. Dr. Gotay joined UBC in 2008 where she continued her primary prevention research through the School of Population and Public Health and the B.C. Cancer Agency. Currently, Dr. Gotay is a leader in the Cancer Prevention Centre where she and her colleagues look at modifiable cancer risk factors and the application and assessment of interventions to modify these behaviours in the population.

\section{RÉ S U Ḿ}

Dre Carolyn Gotay est professeure et elle siège au sein de la Société canadienne du cancer dans le domaine de la prévention primaire du cancer à I'Université de la Colombie-Britannique. Son éducation universitaire a débuté à l'Université de Duke et elle a continué ses études doctorales en psychologie à l'Université de Maryland. Son premier poste fut à l'Université de Calgary et elle concentre ses recherches sur la relation entre la psychologie et le cancer. Dre Gotay a obtenu des postes à l'Université de Gettysburg, à l'Université de Calgary et à l'institut national du cancer (É.U.) où elle était administratrice scientifique de la santé. Par la suite, elle a travaillé à I'Université d'Hawaii, où elle a oeuvré en tant que directrice du programme de prévention et de contrôle du cancer. À travers son cheminement professionnel, Dre Gotay a étudié les soins primaires préventifs en lien avec la qualité de vie, les soins de fin de vie et le bien-être psychosocial des patients. En 2008, elle a eu la chance de continuer sa recherche en soins préventifs primaires à l'Université de la Colombie-Britannique dans le département de santé publique ainsi qu'à l'agence de cancer de la Colombie-Britannique. Dre Gotay demeure une leader au centre de prévention du cancer où elle travaille présentement avec ses collègues pour trouver des facteurs de risque modifiables du cancer et l'application d'interventions pour modifier ces comportements dans la population.

\section{DR. GOTAY, CAN YOU PLEASE TELL US ABOUT YOUR BACKGROUND AND HOW YOU CAME TO WORK IN THE FIELD OF CANCER PREVENTION?}

I am a psychologist by training, but I certainly did not start out with the intention of pursuing cancer prevention research. During the early part of my career in Calgary I was trying to find my role and research passion. I remember the Chair of my department asking me "if there was a link between cancer and psychology." At the time, the field of psycho-oncology was nowhere near a formally recognized discipline and there was not a lot of information written in the literature. I realized that the link between psychology and cancer existed across the entire continuum of cancer control-from prevention to end-of-life care and psycho- 
social wellbeing. I moved through different institutions in the U.S. and spent the bulk of my early career learning about cancer control in the context of patient quality-of-life and clinical trials. When I moved to the University of British Columbia I took on a role in cancer prevention research, which was largely unfamiliar to me. Since arriving in Vancouver, I have learned a great deal. This research integrates fundamentals of psychology; primary cancer prevention involves the identification of modifiable risk factors and then building interventions to affect the behaviour of populations with regard to these factors. Perhaps you would call it happy circumstance, but cancer prevention has become my passion and has certainly re-invigorated my work.

\section{WHAT EXCITES YOU ABOUT CANCER PREVENTION WORK?}

I believe that no matter how well we preserve quality of life for our patients by managing their sequelae, the best outcome would not involve cancer in the first place. In fact, about half of cancers that are diagnosed among people in the population today are largely avoidable-with lung cancer as an example. I don't think we that will ever be able to prevent all cancers, but if we start to use the knowledge that we have to modify behaviour, I am certain that this will leave a more profound impact than any chemotherapeutic.

\section{HOW HAS THE UNDERSTANDING AND CANCER PREVENTION EFFORT CHANGED OVER YOUR CAREER?}

In my first position in 1980 at the University of Calgary, the building I was working in was called the tumor centre, because people we so scared of the word cancer and its association with terminal illness. Cancer awareness today has improved tremendously; the word itself is in the media every single day. Cancer has been demystified. As the baby boomers continue to age, the number of cancers is only going to increase. Over time, more cancer patients and survivors have become activists, with support groups, runs for the cure, etc. This new patient-driven light on cancer as an illness has been important for research funding and public education. However, cancer prevention consistently gets some of the least funding amongst all other realms of cancer research. Health promotion and disease prevention have not benefited as much from this cancer enlightenment. One could make the argument that we have an illness care system as opposed to a healthcare system. With that being said, a notable area where wonderful progress has been made involves smoking prevalence. In B.C. we are between $12-15 \%$ smoking prevalence, which is a huge positive change in comparison to the $25 \%+$ prevalence seen a couple of decades ago.

\section{ASIDE FROM FUNDING ISSUES WITH PRIMARY CANCER PREVENTION WORK, WHAT ARE SOME OF THE CHALLENGES THAT FACE THE FIELD?}

One of the broadest problems that we face is the intrinsic human need for instant gratification to justify our immediate actions. This is particularly notable at the level of policy makers and politicians. It is a difficult situation for them because they need to show return on investment and effective terms of office for re-election. However, the solutions to problems that face the population involve long-term systemic changes that would really require a visionary. We like to see immediate results, and this is not how preventive medicine works. One of the strategies we are using to break through this issue of long-term payoff is to focus on short-term benefits for individuals that reduce risk factor exposure in their lives. For example, by focusing on improved sleep behaviours, people generally feel more rested and productive-whilst also gaining from the cancer risk reduction conferred by sleep optimization. Furthermore, the frustrating thing for the individual is that you can do everything right and still get cancer. Just like we save for our children's futures, we need to ensure that we take steps to make our future the healthiest one possible.

\section{CAN YOU PLEASE DISCUSS SOME OF THE PROJECTS THAT ARE CURRENTLY BEING DEVELOPED BY THE CENTRE OF EXCELLENCE IN CANCER PREVENTION?}

The Centre of Excellence in Cancer Prevention is a vehicle to bring researchers to $U B C$ and build a critical mass of intellect from which we can develop multidisciplinary projects. Scientists within the centre are looking at everything from environmental causes such as arsenic and radon to nutritional epidemiology ${ }^{1}$, as well as methods behind measuring nutritional exposure using biomarkers to track food intake. In the department of physiotherapy, studies are being done to look at the effects of physical activity on breast and colon cancer incidence all the way from the population level to the tissue metabolism level. There is a huge degree of liaising with the Cancer Society to understand the concerns from healthcare providers regarding current policy and gaps in care because they are truly the boots on the ground when it comes to day-to-day patient care. While I have several personal collaborations, I will discuss a few in more detail.

The first project I will discuss is the Worksite Wellness Program [1]. The Cancer Society has found that reaching people through worksites is a phenomenal way to access a large receptive audience-especially since the infrastructure of newsletters and social groups exists in most cases. Some of our interventions included setting up challenges between departments and tailored e-mail reminders to emphasize things like nutrition and wellness, as well as understand barriers at the individual level. This randomized control trial [1] showed a positive change in behaviour using both the e-mail intervention as well as the social support intervention. The wellness parameters included weight loss and increased fruit and vegetable consumption. These findings are

${ }^{1}$ Current efforts in nutritional epidemiology are focused on identifying methods in order to measure nutritional exposure using biomarkers and food intake tracking. 
now being incorporated into worksites across British Columbia. However, one problem that arose was that we noticed that about $80 \%$ of our participants were women. We then started looking at male-dominated worksite wellness in rural B.C., Northwest Territories and the Yukon (especially in work camps and resource industry). This project is currently being implemented and we are seeing that our program is being accepted in a phenomenal way.

Another project looked at a sleep intervention for night shift workers $^{2}$ [2]. Being exposed to light at night has been demonstrated as a risk factor for breast cancer. When this news first came out, it was particularly concerning for women in healthcare, as much of their work was done during overnight shifts. We applied a telephone-delivered sleep intervention in 47 night shift workers delivered by the team at the UBC Hospital sleep clinic. This resulted in a statistically and clinically significant quality of sleep improvement that lasted 1 year post intervention. The next step will be to make this intervention more available to the larger population of night shift workers.

The final project I will discuss is a prostate cancer survivor study. ${ }^{3}$ Prevention is key in cancer realms with a relatively long life expectancy, especially in the survivor population. Since prostate cancer is the most commonly diagnosed form of cancer in males (in Canada), we wanted to improve long-term outcomes post remission for patients. We identified nutrition as a key area for this demographic because many of the medications cause bone density changes, weight changes, muscle loss, and alteration in muscle activity. Our intervention was a cooking class for the men and their wives. This was led by a chef who taught the couples to do new things with old foods that they knew and loved, in order to improve the health profile of their meals. We are currently in the process of following their health and emotional status changes throughout the intervention and look forward to analyzing the results.

You can certainly see how it takes a creative, interdisciplinary approach to make an impact in the cancer prevention realm. Throughout all projects, our core mandate is sustainability, especially when we look forward after the period of funding is over.

\section{HEALTHCARE IS CRITICISED FOR BEING REFLEXIVE; WE RESPOND TO ILLNESS AS IT PRESENTS IN THE POPULATION. WITHIN THE CONTEXT OF STRAINED HEALTH RESOURCES THAT WE FACE IN MANY AREAS OF CANADA, WHAT ROLE DOES PREVENTION PLAY FOR THE FUTURE OF CANADIAN HEALTHCARE? HOW DO THE STUDENTS OF HEALTHCARE ENGAGE WITH THE PREVENTIVE SIDE OF MEDICINE?}

If we don't embrace preventive medicine, we are going to be far more overwhelmed in the future compared to today. The key is support from the leadership. Policy around billing for preventive counselling is an essential issue that must be addressed. The team-based approach to healthcare is most promising. No single part of the health team should take the full load of preventive medicine. As a learner and a student, it is your role to identify individuals in your teams who engage with preventive practices and learn from them. If you do not know the resources, that is totally alright, but it is absolutely your responsibility to be tapped into your network to know where to find those resources. Students need to look forward at the health system they will be inheriting, and as such it is really up to you to make preventive medicine a priority in your own practice.

\section{ACKNOWLEDGEMENTS}

The author would kindly like to thank Dr. Carolyn Gotay, PhD, for taking her time to answer these questions and explain her research field. For more information on the work conducted by Dr. Gotay and her colleagues, please visit https://cancerprevent.ca/.

\section{REFERENCES}

1. Monro M, Amick B, Bottorf J, et al. Be well at work: a randomized study of innovative workplace cancer prevention interventions. Poster session presented at: Semiahmoo 2014, the Annual Occupational, Environmental and Public Health Conference; 2014 Jan; Blaine, WA.

2. Gotay $\mathrm{C}$, Shen $\mathrm{H}$, Munoz C. The impact of an intervention to improve sleep quality in normal, overweight and obese female shift workers. Can J Diabetes. $2015 ; 39(1):$ S68.

\footnotetext{
${ }^{2}$ The sleep intervention consisted of 12 telephone-delivered cognitive behavioral therapy sessions delivered by an experienced sleep counsellor. These sessions focused on changing unhealthy behavioral patterns by modifying thought processes.

${ }^{3}$ This study is currently in progress and therefore a formal citation is not provided. For more information, refer to http://spph.ubc.ca/cooking-class-study-seeks-toincrease-health-outcomes-for-prostate-cancer-survivors-and-their-partners/.
} 